(c) American Dairy Science Association, 2005.

\title{
Distribution of Conjugates of Alkylphenols in Milk from Different Ruminant Species
}

\author{
M. Kilic ${ }^{1}$ and R. C. Lindsay ${ }^{2}$ \\ ${ }^{1}$ Department of Food Engineering, Istanbul Technical University, 34469 Maslak, Turkey \\ ${ }^{2}$ Department of Food Science, University of Wisconsin-Madison, Madison 53706
}

\begin{abstract}
Conjugated alkyphenols in milk constitute a reservoir for species-related alkylphenols in dairy products. The distributions of conjugated alkylphenols between different conjugation pathways (sulfation, phosphorylation, and glucuronidation) were determined in cows', sheep's, and goats' milk. Species-related p- and m-cresols and 3- and 4-ethylphenols were found to be mostly conjugated with sulfate with minor amounts associated with phosphate and glucuronide conjugates in all milks. Similar distributions were observed for alkylphenols in the urine and milk from the same ewe. Phenol was present in minor amounts distributed sporadically between different conjugates in the milks. Sulfate-conjugated phenol was not detected in the ewe's urine, which included equal amounts of glucuronide and phosphate conjugates. The amounts of alkylphenols were different in sheep's milk from different sources suggesting that there were effects of feed, breed, and individual animal variation on the metabolism of alkylphenols.
\end{abstract}

(Key words: alkylphenol conjugates, ruminant milk)

\section{INTRODUCTION}

Alkylphenols have been identified in dairy products (Urbach et al., 1972; Ramshaw, 1985; Ha and Lindsay, 1991a,b), and are expected to contribute to characteristic species-like flavors at low (ppb) levels. The major alkylphenol present in ruminant milks is p-cresol, which in excessive levels provides barny and animallike flavors (Lopez and Lindsay, 1993). Species-related flavors of sheep's milk are also provided by 3 - and 4ethylphenols (Ha and Lindsay, 1991a). Other alkylphenols, including 2-ethylphenol, m-cresol, and phenol, provide background flavor notes in milk. Free alkylphenols are present at low levels in milk fat (Han, 1994) with larger amounts bound as conjugates in skim milk (Brewington et al., 1973, 1974; Lopez and Lindsay,

Received August 22, 2004.

Accepted September 29, 2004.

Corresponding author: Meral Kilic; e-mail: meral.kilic@itu.edu.tr.
1993). Thus, there is a large reservoir of alkylphenols in milk from ruminants that can be used to intensify species-related flavors in dairy products.

Conjugation is a detoxification mechanism that enables an animal to solubilize xenobiotics and excrete them in the urine. The main site for conjugation is the liver, but the intestine, kidneys, lungs, and skin also conjugate xenobiotics. The preferred conjugation mechanism for a substrate depends on the species, nature of the compound, the transferase enzyme, and availability of the cosubstrate. Monohydric phenols are commonly conjugated at the hydroxyl group by sulfation, glucuronidation, and to a lesser extent, by acetylation and phosphorylation (Mulder, 1990). Conjugates of pcresol, 4-ethylphenol, and phenol were identified early in the urine of ruminants (Grant, 1948; Suemitsu et al., 1970; Kao et al., 1979).

Despite extensive studies about the metabolism and urinary excretion of conjugates of phenol (Caldwell, 1980; Mulder, 1982), limited information is available about the identity and quantity of different alkylphenol conjugates present in milk. Understanding of the distribution and quantities of species-related alkylphenols between different conjugation mechanisms could be used to facilitate release of these flavor compounds in dairy products. The present study was undertaken to investigate the amounts of different conjugates of alkylphenols present in ruminant milks with a particular emphasis on sheep's milk using currently available analytical methods.

\section{MATERIALS AND METHODS}

\section{Materials}

Pasteurized cows' milk was obtained from the Babcock Dairy Store, University of Wisconsin-Madison. Pasteurized goats' milk was purchased from a local retail store. Raw sheep's milk was obtained from Spooner Agricultural Research Station, University of Wisconsin-Madison (source 1), and from 2 local sheep farmers (sources 2 and 3). Sheep's milk was batch-pasteurized at $63^{\circ} \mathrm{C}$ for $30 \mathrm{~min}$ before analysis. Milk and urine from the same sheep was obtained from source 3. 
Feeding regimens between local farms were reportedly different; sheep from source 3 were on a pasture rotation, including blue grass, white and red clover, and orchardgrass; sheep from source 2 had a more limited supply of pasture without rotation, including red and white clover and orchardgrass. Sheep from source 1 were mostly held in confinement and fed alfalfa hay, but some of the sheep had limited access to pasture, which included kura clover and orchardgrass. All sheep were reportedly fed a supplemental grain mixture at milking in the parlor.

All solvents used were HPLC grade.

\section{Extraction of Conjugated Alkylphenols}

Conjugated alkylphenols in skim milk were analyzed using the methods of Zeng (1997) and Lopez and Lindsay (1993) with some modifications. Pasteurized whole milk was centrifuged at $15,000 \times g$ at $4^{\circ} \mathrm{C}$ for $30 \mathrm{~min}$ (Sorvall refrigerated centrifuge, DuPont Inst., Des Plaines, IL) to separate cream and skim milk fractions. Skim milk was then filtered through glass wool to remove residual fat.

Conjugated alkylphenols in skim milk were isolated by elution through an open column of Amberlite XAD2 beads (Supelco, Bellefonte, PA). The beads (15-g batches) were prepared by immersion in $25 \mathrm{~mL}$ of methanol for $10 \mathrm{~min}$ and then in $25 \mathrm{~mL}$ of double-distilled water for $10 \mathrm{~min}$. Beads were then placed into the column and backwashed with $50 \mathrm{~mL}$ of double-distilled water. After removing the water, $2 \mathrm{~kg}$ of skim milk was passed through 4 XAD-2 columns at a flow rate of 10 $\mathrm{mL} / \mathrm{min}$. Each column was washed with $100 \mathrm{~mL}$ of double-distilled water and backwashed with another 50 $\mathrm{mL}$ of double-distilled water. After addition of $50 \mathrm{~mL}$ of methanol, each column was held for 10 min to allow penetration of the solvent into the beads. Alkylphenols adsorbed by the column were eluted with $100 \mathrm{~mL}$ of methanol at a flow rate of $2.5 \mathrm{~mL} / \mathrm{min}$. Methanol extracts were concentrated in round-bottom flasks (250 $\mathrm{mL}$ ) at $40^{\circ} \mathrm{C}$ using a rotary vacuum evaporator until 3 $\mathrm{mL}$ of residue was left. Residues obtained from each elution were collected by washing with $3 \mathrm{~mL}$ of distilled water and all fractions were combined in a final extract. Each concentrate obtained was clarified by extraction (3 times) with ether:pentane (3:2) to remove artifacts from the XAD-2 column material. The final extract contained the conjugates from approximately $100 \mathrm{~g}$ of skim milk per $\mathrm{mL}$. The extracts were kept at $-20^{\circ} \mathrm{C}$ until analysis.

\section{Hydrolysis of Conjugates}

Two milliliters of acetate buffer at $\mathrm{pH} 5$ and $50 \mu \mathrm{L}$ of o-cresol (10 mg/100 mL of methanol) as an internal standard were added into $500-\mu \mathrm{L}$ portions of skim milk extracts. Conjugated alkylphenols were released by incubating the extract mixtures with 100 units of acid phosphatase (EC 3.1.3.2) type I from wheat germ or 100 units of arylsulfatase (EC 3.1.6.1) type VIII from abalone entrails containing negligible amounts of $\beta$-Dglucuronidase activity (less than 13 units of $\beta$-D-glucuronidase per 100 units of arylsulfatase) or 1000 units of $\beta$-D-glucuronidase (EC 3.2.1.31) from Escherichia coli (Sigma Chemical Co., St. Louis, MO) at $37^{\circ} \mathrm{C}$ for $24 \mathrm{~h}$. After incubation, mixtures were cooled to room temperature and acetone was added (1:1) to prevent formation of emulsions and improve the recovery of alkylphenols from the aqueous phase. Free alkylphenols released by each enzyme were then extracted 3 times with ethyl ether (1:1). Ethyl ether extracts were washed with $2 \mathrm{~mL}$ of saturated $\mathrm{NaCl}$ solution to remove residual aqueous components. Final extracts were dried over excess anhydrous $\mathrm{Na}_{2} \mathrm{SO}_{4}$, and then concentrated under a slow stream of nitrogen to near dryness. Control samples were prepared by including only the milk extract without the enzymes or each enzyme alone to correct for interferences that might occur.

The acidic components in each concentrate subsample were neutralized by adding $100 \mu \mathrm{L}$ of $0.2 \mathrm{M} \mathrm{Na}_{2} \mathrm{CO}_{3}$. The $\mathrm{pH}$ of the concentrates was adjusted to $\mathrm{pH} 12 \mathrm{using}$ $50-\mu \mathrm{L}$ portions of $1 \mathrm{~N} \mathrm{NaOH}$ and the addition of 100 $\mu \mathrm{L}$ of phosphate buffer at $\mathrm{pH} 12$. Free alkylphenols were derivatized by incubating buffered mixtures with $600 \mu \mathrm{L}$ of dansyl chloride (5-dimethylamino-napthalene-1-sulfonyl chloride, $5 \mathrm{mg} / \mathrm{mL}$ acetone; Aldrich Chemical Co., Milwaukee, WI) at $45^{\circ} \mathrm{C}$ for $20 \mathrm{~min}$. After cooling to room temperature, excess dansyl chloride in the mixtures was hydrolyzed with 3 drops of $1 \mathrm{~N} \mathrm{NaOH}$. Dansylated free alkylphenols were extracted into 500 $\mu \mathrm{L}$ of hexane, and $20-\mu \mathrm{L}$ aliquots were used for analysis with HPLC. Conjugated alkylphenols in sheep urine were determined using the same procedures except that $100 \mathrm{~mL}$ samples were used for isolation of conjugates, and $100 \mu \mathrm{L}$ of urine extract obtained from Amberlite $\mathrm{XAD}-2$ elution (equivalent to $2.5 \mathrm{~g}$ of urine) and $100 \mu \mathrm{L}$ of internal standard were used in the enzyme incubation mixtures.

\section{HPLC Analysis of Dansylated Free Alkylphenols}

Normal phase HPLC was performed using a Lichrosorb Si-60 column $(5 \mu \mathrm{m}, 250 \times 4 \mathrm{~mm}$ i.d.; Alltech Assoc., Inc., Deerfield, IL). The HPLC system included a Beckman 110B solvent delivery module (Beckman Instruments, Inc., Berkeley, CA), and a $20-\mu \mathrm{L}$ sample loop. The mobile phase was $1.6 \%$ acetone in 2,2,4-trimethylpentane at a flow rate of $1.5 \mathrm{~mL} / \mathrm{min}$. Detection of dansyl derivatives was carried out with a Waters model 420 
Table 1. Conjugated alkylphenol profiles of skim milk from different ruminant species.

\begin{tabular}{|c|c|c|c|}
\hline \multirow[b]{2}{*}{ Conjugate compound } & \multicolumn{3}{|c|}{ Concentration $(\mathrm{ppb})^{1}$} \\
\hline & Sheep & Goat & Cow \\
\hline \multicolumn{4}{|l|}{ 3- and 4-Ethylphenols ${ }^{2}$} \\
\hline sulfate & $11.5 \pm 1.2$ & $87.8 \pm 0.1$ & $17.4 \pm 0.2$ \\
\hline phosphate & $\mathrm{ND}^{3}$ & $2.8 \pm 0.2$ & $1.0 \pm 0.04$ \\
\hline glucuronide & ND & $1.4 \pm 0.3$ & ND \\
\hline \multicolumn{4}{|l|}{$\mathrm{p}$ - and m-Cresols ${ }^{2}$} \\
\hline sulfate & $206.0 \pm 30.0$ & $184.4 \pm 2.9$ & $98.6 \pm 3.0$ \\
\hline phosphate & $8.7 \pm 0.01$ & $13.4 \pm 0.5$ & $12.9 \pm 1.0$ \\
\hline glucuronide & $0.5 \pm 0.01$ & $0.4 \pm 0.3$ & $1.1 \pm 0.1$ \\
\hline \multicolumn{4}{|l|}{ Phenol } \\
\hline sulfate & $2.2 \pm 0.2$ & ND & $0.8 \pm 0.1$ \\
\hline phosphate & ND & $0.5 \pm 0.01$ & $0.6 \pm 0.1$ \\
\hline glucuronide & $0.2 \pm 0.1$ & ND & ND \\
\hline
\end{tabular}

\footnotetext{
${ }^{1}$ Average \pm standard deviation of duplicate samples. Skim milk extracts were incubated separately with enzymes, 100 units of acid phosphatase, 100 units of arylsulfatase, and 1000 units of $\beta$-D-glucuronidase.

${ }^{2}$ Compounds coeluted.

${ }^{3} \mathrm{ND}=$ Not detected, below $0.02 \mathrm{ppb}$.
}

fluorescence detector (Waters Associates, Inc., Milford, MA) with a gain setting of 8 which was set at an excitation wavelength of $360 \mathrm{~nm}$ and an emission wavelength of $425 \mathrm{~nm}$. Chromatograms were recorded using a Spectra Physics model 4200 computing integrator (Spectra Physics, San Jose, CA) with a chart speed of $0.5 \mathrm{~cm} /$ min. Alkylphenols in chromatograms were identified by coincidence of retention times between unknown and authentic compounds.

\section{RESULTS AND DISCUSSION}

The HPLC method used in quantification had low detection limit (0.02 ppb) that allowed measurements of small amounts of alkylphenols present in milk (Zeng, 1997). However, some compounds coeluted, including p- and m-cresols, and 3- and 4-ethylphenols; therefore they were reported together.

All of the milk samples contained mostly sulfate conjugates of $\mathrm{p}$ - and m-cresols and 3- and 4-ethylphenols with minor amounts of phosphate and glucuronide conjugates (Tables 1 and 2). Lopez and Lindsay (1993) also found that alkylphenols in cows' and goats' skim milk were mostly conjugated with sulfate with minor amounts bound as glucuronides. Brewington et al. $(1973,1974)$ reported glucuronide and sulfate conjugates of p-cresol and 4-ethylphenol in cows' skim milk, but only indicated estimates of relative abundances of the compounds. Grant (1948) identified 4-ethylphenyl sulfate in goat's urine. Notably, for the current study, the overall distribution of alkylphenols between sulfate, phosphate, and glucuronide conjugates were similar in all ruminant milk samples even though species differences had previously been reported for conjugation of phenolic compounds in urine (Capel et al., 1972; Williams, 1974; Caldwell, 1980).

Sheep's and goats' milk had higher amounts of p- and m-cresols than cows' milk (Table 1). Moio et al. (1993) and Lopez and Lindsay (1993) found higher amounts of p-cresol in ewes' and goats' milk than in cows' milk. p-Cresol was the major alkylphenol present in all the milks. The major alkylphenol in sheep's (Bassett et al., 1955; Braden et al., 1967; Martin, 1982) and cows' (Suemitsu et al., 1970) urine has also been found to be p-cresol. p-Cresol has a characteristic barn-like flavor that blends with the more medicinal notes of m-cresol in milk (Ha and Lindsay, 1991a).

Goats' milk contained the highest amounts of 3- and 4-ethylphenols among the milk samples analyzed (Table 1). 3-Ethylphenol is a characteristic species-related alkylphenol with a sheep-like and phenolic flavor. 4Ethylphenol possesses stronger sheep-like flavor character with a particular sheep yard-like aroma (Ha and Lindsay, 1991a). The presence of these compounds (3and 4-ethylphenols) likely contributes to the strong flavors of goats' milk. The sheep's milk sample had lower amounts of 3- and 4-ethylphenols than goats' milk, and cows' milk contained slightly higher amounts of 3- and 4-ethylphenols than the sheep's milk. However, analysis of sheep's milk from different sources revealed that some variation occurred between different milk samples (Table 2).

Minor amounts and sporadic distributions were obtained for phenol conjugates in all milk samples (Tables 1 and 2). In earlier reports, phenol was thought to be conjugated mostly with glucuronide with lesser amounts as sulfate in the urine (Suemitsu et al., 1970; Williams, 1974; Kao et al., 1979). In this study, how- 
Table 2. Conjugated alkylphenol profiles of ewe's skim milk from different local suppliers with different feeding regimens.

\begin{tabular}{|c|c|c|c|}
\hline \multirow[b]{2}{*}{ Conjugate compound } & \multicolumn{3}{|c|}{ Concentration $(\mathrm{ppb})^{1}$} \\
\hline & Source $1^{2}$ & Source $2^{3}$ & Source $3^{4}$ \\
\hline $\begin{array}{l}\text { 3- and } 4 \text {-Ethylphenols } \\
\text { sulfate } \\
\text { phosphate } \\
\text { glucuronide }\end{array}$ & $\begin{array}{l}11.5 \pm 1.2 \\
\mathrm{ND}^{6} \\
\mathrm{ND}\end{array}$ & $\begin{aligned} & 42.7 \pm 0.7 \\
& 1.9 \pm 0.3 \\
& \mathrm{ND}\end{aligned}$ & $\begin{array}{r}37.8 \pm 0.5 \\
1.8 \pm 0.4 \\
0.8 \pm 0.1\end{array}$ \\
\hline $\begin{array}{l}\text { p- and m-Cresols }{ }^{5} \\
\text { sulfate } \\
\text { phosphate } \\
\text { glucuronide }\end{array}$ & $\begin{array}{r}206.0 \pm 30.0 \\
8.7 \pm 0.01 \\
0.5 \pm 0.01\end{array}$ & $\begin{aligned} 225.9 & \pm 1.8 \\
10.0 & \pm 1.6 \\
0.3 & \pm 0.1\end{aligned}$ & $\begin{aligned} 652.7 & \pm 8.7 \\
21.0 & \pm 0.5 \\
2.9 & \pm 0.03\end{aligned}$ \\
\hline $\begin{array}{l}\text { Phenol } \\
\text { sulfate } \\
\text { phosphate } \\
\text { glucuronide }\end{array}$ & $\begin{array}{c}2.2 \pm 0.2 \\
\mathrm{ND} \\
0.2 \pm 0.1\end{array}$ & $\begin{array}{l}\mathrm{ND} \\
0.9 \pm 0.2 \\
0.7 \pm 0.1\end{array}$ & $\begin{array}{l}\text { ND } \\
\quad 0.6 \pm 0.2 \\
\text { ND }\end{array}$ \\
\hline
\end{tabular}

${ }^{1}$ Average \pm standard deviation of duplicate samples.

${ }^{2}$ Source 1 sheep were mostly in confinement fed with alfalfa hay with some sheep on pasture (kura clover and orchardgrass).

${ }^{3}$ Source 2 sheep were on pasture (red and white clover, orchardgrass).

${ }^{4}$ Source 3 sheep were on a pasture rotation (blue grass, white and red clover, orchardgrass).

${ }^{5}$ Compounds coeluted.

${ }^{6} \mathrm{ND}=$ Not detected, below $0.02 \mathrm{ppb}$.

ever, the glucuronide conjugate of phenol was not detected in cows' and goats' milk, and only minor amounts were present in sheep's milk. Furthermore, the glucuronide conjugates of other phenols were only found at minor amounts compared with sulfate conjugates in all milk samples.

The effect of feeding regimen on alkylphenols in sheep's milk is illustrated in Table 2. Sulfate conjugates of $\mathrm{p}$ - and m-cresols were 3-fold higher in milk from source 3 than in milks from sources 1 and 2 . The concentrations of sulfate conjugates of 3- and 4-ethylphenols were about 4 times higher in ewes' milk from source 2 and 3 than in ewes' milk from source 1. Ewes from sources 2 and 3 had similar feeding regimens that included mostly pasture, but they also received grain concentrate supplementation at milking. Pasture was also available to some of the sheep in source 1 , but only to a limited number of the animals.

The higher concentrations of $\mathrm{p}$ - and m-cresols in milk from source 3 than in source 2 could reflect the effect of variety of pasture that was available to the ewes. Formononetin, a constituent of subterranean clover, has been found to be degraded into mostly p-cresol with minor amounts of 4-ethylphenol when administered intraruminally to sheep (Batterham et al., 1965; Braden et al., 1967; Batterham et al., 1971). Isoflavones in subterranean clover, such as biochanin A and genistein, have been shown to be degraded in the sheep rumen to yield 4-ethylphenol as an end product (Batterham et al., 1965; Braden et al., 1967; Batterham et al., 1971). Because a varying distribution of alkylphenols in differ- ent conjugate forms was observed between the ewes' milk from different sources, feed, breed, and individual animal characteristics probably affect the metabolism of alkylphenols. The effect of feed on the flavor of milk has been studied, including that for the cow (Urbach, 1990), the goat (Skjevdal, 1979), and the sheep (Moio et al., 1996). Considerable variation has been observed within and between species, which likely results from the natural variations noted above.

Urine and milk from the same ewe were analyzed for conjugated alkylphenols; the amounts of conjugated alkylphenols in milk were $1.3,0.8$, and $0.5 \%$ of the amounts present in the urine for $\mathrm{p}$ - and m-cresols, 3and 4-ethylphenols, and phenol, respectively (Table 3). The same trend as in milk was obtained for the urine for $\mathrm{p}$ - and m-cresols and 3- and 4-ethylphenols where sulfate was the major conjugate. Similar amounts of phosphate and glucuronide conjugates were found for each of the alkylphenols. Phosphate and glucuronide conjugates of phenol were present at approximately equal concentrations, but sulfate conjugates of phenol were absent in the urine. Kao et al. (1979) determined that $\left[{ }^{14} \mathrm{C}\right]$ phenol was excreted in sheep's urine mainly as glucuronide (49\%) and sulfate $(32 \%)$ conjugates with small amounts associated with phosphate (12\%). Lopez and Lindsay (1993) previously reported that sheep's milk appeared to contain mostly phosphate conjugates of alkylphenols based on hydrolysis studies using crude enzymes. However, these observations were not confirmed in the current study. 
Table 3. Distribution of conjugated alkylphenols in the milk and urine from the same ewe. ${ }^{1}$

\begin{tabular}{lcr}
\hline & \multicolumn{2}{c}{ Concentration $(\mathrm{ppb})^{2}$} \\
\cline { 2 - 3 } Conjugate compound & Skim milk & Urine \\
\hline 3- and 4-Ethylphenols ${ }^{3}$ & $56.9 \pm 1.0$ & $6403 \pm 16$ \\
$\quad$ sulfate & $1.5 \pm 0.3$ & $620 \pm 79$ \\
phosphate & $3.0 \pm 0.03$ & $695 \pm 130$ \\
glucuronide & & \\
p- and m-Cresols & & \\
sulfate & $443.3 \pm 8.2$ & $25,256 \pm 77$ \\
phosphate & $24.0 \pm 0.4$ & $5314 \pm 460$ \\
glucuronide & $14.2 \pm 0.3$ & $5298 \pm 891$ \\
Phenol & & \\
$\quad$ sulfate & $\mathrm{ND}^{4}$ & $\mathrm{ND}$ \\
phosphate & $1.0 \pm 0.1$ & $86 \pm 6$ \\
glucuronide & $\mathrm{ND}$ & $97 \pm 8$ \\
\hline
\end{tabular}

${ }^{1}$ The ewe was from source 3 on a pasture rotation (blue grass, white and red clover, orchardgrass).

${ }^{2}$ Average \pm standard deviation of duplicate samples.

${ }^{3}$ Compounds coeluted.

${ }^{4} \mathrm{ND}=$ Not detected, below $0.02 \mathrm{ppb}$.

Generally, glucuronidation and sulfation are the 2 major competing conjugation reactions for phenol depending on its concentration (Mulder and Meerman, 1978). Sulfation exhibits a high affinity, but low capacity reaction, whereas glucuronidation exhibits a low affinity, but high capacity reaction. As a result, sulfation predominates at low substrate concentrations and glucuronidation becomes dominant at high substrate concentrations (Mulder, 1990). Therefore, at low levels of phenols or their precursors originating from feed, sulfation would be the primary route for conjugation in the animal compared with experimentally administered, metabolically challenging doses of phenols in metabolic studies. The route of administration of phenol has been shown to be a factor in the metabolism of this compound. Orally administered phenol was excreted mostly as sulfate conjugate in the urine of rats, whereas the glucuronide conjugate was equally present when phenol was introduced intraperitoneally (Mulder, 1981; Kenyon et al., 1995). Furthermore, p- and mcresols and 3- and 4-ethylphenols might be handled differently than phenol in animal metabolism.

The concentrations of conjugated alkylphenols in milk were found at amounts less than $1.5 \%$ of that present in the urine of the sheep (Table 3). Prelusky et al. (1987) reported that less than $0.25 \%$ of a dose of deoxynivalenol, a mycotoxin, was excreted into milk of lactating sheep. Minor amounts of fungicides and herbicides were conjugated mostly with sulfate in milk and urine of goat (Paulson et al., 1973; Paulson and Jacobsen, 1974; Chukwudebe et al., 1994).

\section{CONCLUSIONS}

Species-related alkylphenols were conjugated mostly with sulfate, whereas only minor amounts were bound as phosphate and glucuronide conjugates in cows', ewes', and goats' milk. Goats' milk was rich in 3- and 4-ethylphenols compared with ewes' and cows' milk. The amounts of $\mathrm{p}$ - and m-cresols were high in ewes' and goats' milk, possibly differentiating these milks from cows' milk.

The amounts of alkylphenols varied in ewes' milk obtained from different local sources, suggesting that the feed, breed, and individual animal affect the metabolism of the alkylphenols. The amounts and distributions of alkylphenols in ewes' urine were found to be similar to those in milk. Results from this study indicated that species-related alkylphenols were predominantly present as sulfate conjugates in ruminant milks when phenolic compounds or their precursors were normally ingested via feed by the animal. Further studies are needed to determine the factors, such as feeding regimen, that affect the amounts of conjugated alkylphenols in milk so that this information could be used to manipulate the amounts of these flavor precursors in milk and dairy products.

\section{REFERENCES}

Bassett, E. G., O. K. Sewel, and E. P. White. 1955. Sex hormone studies on sheep. N.Z. J. Dairy Sci. Technol. 36:437-449.

Batterham, T. J., N. K. Hart, and J. A. Lamberton. 1965. Metabolism of oestrogenic isoflavones in sheep. Nature 206:509.

Batterham, T. J., D. A. Shutt, N. K. Hart, A. W. Braden, and H. J. Tweeddale. 1971. Metabolism of intraruminally administered [414C]formononetin and [4-14C]biochanin A in sheep. Aust. J. Agric. Res. 22:131-138

Braden, A. W. H., N. K. Hart, and J. A. Lamberton. 1967. The oestrogenic activity and metabolism of certain isoflavones in sheep. Aust. J. Agric. Res. 18:335-348.

Brewington, C. R., O. W. Parks, and D. P. Schwartz. 1973. Conjugated compounds in cows' milk. J. Agric. Food Chem. 21:38-39.

Brewington, C. R., O. W. Parks, and D. P. Schwartz. 1974. Conjugated compounds in cows' milk. II. J. Agric. Food Chem. 22:293-294.

Caldwell, J. 1980. Comparative aspects of detoxification. Pages 85114 in Enzymatic Basis of Detoxification. Vol. 1. W. B. Jakoby, ed. Academic Press, Orlando, FL.

Capel, I. D., M. R. French, P. Millburn, R. L. Smith, and R. T. Williams. 1972. The fate of $[14 \mathrm{C}]$ phenol in various species. Xenobiotica 2:25-34.

Chukwudebe, A. C., P. G. Wislocki, D. R. Sanson, T. D. J. Halls, and W. J. A. VandenHeuvel. 1994. Metabolism of thiabendazole in laying hen and lactating goats. J. Agric. Food Chem. 42:29642969.

Grant, J. K. 1948. p-Ethylphenylsulfuric acid in goat urine. Biochem. J. 43:523-524.

Ha, J. K., and R. C. Lindsay. 1991a. Contributions of cow, sheep, and goats' milks to characterizing branched-chain fatty acids and phenolic flavors in varietal cheeses. J. Dairy Sci. 74:3267-3274.

Ha, J. K., and R. C. Lindsay. 1991b. Volatile branched-chain fatty acids and phenolic compounds in aged Italian cheese flavors. J. Food Sci. 56:1241-1247, 1250.

Han, L. H. 1994. Measurement of alkylphenols in fatty foods. M.S. Thesis, Univ. Wisconsin, Madison, WI. 
Kao, J., J. W. Bridges, and J. K. Faulkner. 1979. Metabolism of [14C]phenol by sheep, pig, rat. Xenobiotica 9:141-147.

Kenyon, E. M., M. E. Seeley, D. Janszen, and M. A. Medinsky. 1995. Dose-, route-, and sex-dependent urinary excretion of phenol metabolites in B6C3F1 mice. J. Toxicol. Environ. Health 44:219-233.

Lopez, V., and R. C. Lindsay. 1993. Metabolic conjugates as precursors for characterizing flavor compounds in ruminant milks. J. Agric. Food Chem. 41:446-454.

Martin, A. K. 1982. The origin of urinary aromatic compounds excreted by ruminants. 3 . The metabolism of phenolic compounds to simple phenols. Br. J. Nutr. 48:497-507.

Moio, L., J. Dekimpe, P. Etievant, and F. Addeo. 1993. Neutral volatile compounds in the raw milks from different species. J. Dairy Res. 60:199-213.

Moio, L., L. Rillo, A. Ledda, and F. Addeo. 1996. Odorous constituents of ovine milk in relationship to diet. J. Dairy Sci. 79:1322-1331.

Mulder, G. J. 1981. Sulfation of drugs and related compounds. CRC Press, Inc., Boca Raton, FL.

Mulder, G. J. 1982. Conjugation of phenols. Pages 247-269 in Metabolic Basis of Detoxication. W. B. Jakoby, J. R. Bend, and J. Caldwell, ed. Academic Press, New York, NY.

Mulder, G. J. 1990. Conjugation Reactions in Drug Metabolism. Taylor \& Francis, Bristol, PA.

Mulder, G. J., and J. H. N. Meerman. 1978. Glucuronidation and sulphation in vivo and vitro: Selective inhibition of sulphation by drugs and deficiency of inorganic sulphate. Pages 389-397 in Conjugation Reactions in Drug Biotransformation. A. Aitio, ed. Elsevier/North-Holland Biomedical Press, Amsterdam, The Netherlands.
Paulson, G. D., and A. M. Jacobsen. 1974. Isolation and identification of propham (isopropyl carbanilate) metabolites from animal tissues and milk. J. Agric. Food Chem. 22:629-631.

Paulson, G. D., A. M. Jacobsen, R. G. Zaylskie, and V. J. Feil. 1973. Isolation and identification of propham (isopropyl carbanilate) metabolites from the rat and goat. J. Agric. Food Chem. 21:804-811.

Prelusky, D. B., D. M. Veira, H. L. Trenholm, and B. C. Foster. 1987. Metabolic fate and elimination in milk, urine, and bile of deoxynivalenol following administration to lactating sheep. J. Environ. Sci. Health. B22:125-148.

Ramshaw, E. H. 1985. Aspects of the flavour of phenol, methylphenol, and ethylphenol. CSIRO Food Res. Q. 45:20-22.

Skjevdal, T. 1979. Flavour of goats' milk: A review of studies on the sources of its variation. Livest. Prod. Sci. 6:397-405.

Suemitsu, R., S. Fujita, M. Yoshimura, H. Gen, A. Yuasa, and J. Ushijima. 1970. Studies on the components of mammalian urine. Part VII. Aglycon components of glucuronides in the urine of dairy cows. Agric. Biol. Chem. 34:957-960.

Urbach, G. 1990. Effect of feed on flavor in dairy foods. J. Dairy Sci. 73:3639-3650.

Urbach, G., W. Stark, and D. A. Forss. 1972. Volatile compounds in butter oil II. Flavour and flavour thresholds of lactones, fatty acids, phenols, indole and skatole in deodorized synthetic butter. J. Dairy Res. 39:35-47.

Williams, R. T. 1974. Inter-species variations in the metabolism of xenobiotics. Biochem. Soc. Trans. 2:359-377.

Zeng, Q. 1997. Influence of milkfat on the formation of flavor compounds in Cheddar cheese. Ph.D. Diss., Univ. Wisconsin, Madison, WI. 